The Executive Secretary read the following memorial prepared by Professor Kenneth Colegrove:

\title{
NORMAN DWIGHT HARRIS
}

Norman Dwight Harris died in his home in Daytona Beach on September 5, 1958. In 1907, he was one of the original members of the American Society of International Law, and since 1944, a life member.

In 1906, he was appointed Professor of European Diplomatic History in Northwestern University. In 1916 he founded the Department of Political Science in the same institution. Throughout his active career, he contributed numerous leading articles and book reviews to the AmERICAN Journal of International LAw, as well as to other learned journals. In the fields of diplomacy and international relations, he published two outstanding treatises. His Intervention and Colonization of Africa appeared in 1914, with a revised edition in 1927. His Europe and Asia was published in 1925. Both volumes enjoyed a high reputation in foreign offices throughout the world, and were widely used as textbooks in colleges and universities. Professor Harris was an early advocate of a program of a consistent and moderate national policy as the most feasible path to international peace.

The following memorial was prepared by Professor JoHN B. WhiтToN of Princeton University :

\section{GILBERT GIDEL}

An exceptionally cruel loss has been suffered by the international law fraternity in the passing of one of its most eminent and beloved members, Professor Gilbert Gidel. Best known as Professor at the Faculty of Law at Paris and the Institute of Political Studies, Professor Gidel made many notable contributions in the field of law, especially international law and constitutional law. His writings are brilliant and numerous; even some of his articles have become classics. His chef d'oeuvre is, of course, the Droit International de la Mer, of which only three volumes have appeared, namely, La haute mer (1932), Les eaux intérieures (1932), and La mer territoriale (1934), all now out of print. It was indeed a tragic loss when the notes for several more volumes, those on distress and force majeure, international straits, and maritime warfare, went down with the ship carrying them to England and safety in 1940.

Professor Gidel was a distinguished advocate as well as teacher and scholar. He represented France and other states many times before the Permanent Court of International Justice and other judicial and arbitral tribunals. For many years he served as Secretary and then as President of the Hague Academy of International Law, where he himself lectured several times. He had a very active part in the work of the Institute of International Law, from 1921 until the year of his death. His last official position representing his country was at the Geneva Conference on the Law of the Sea in 1958. 
He served with distinction as Rector of the Academy of Paris at an unusually difficult period, the years of the second World War. Before the fall of France he served as adviser to the Ministry of Marine with the rank of Colonel. In the First World War, too, he left his mark; serving four years in that conflict, he rose to the rank of Captain, and won not only the Croix de Guerre but also the Legion of Honor in the military category.

Professor Gidel has many friends and colleagues in this country, where he had lectured, notably at Yale and Princeton. He was present at the 25th annual meeting of this Society in 1931 and took a part in its proceedings. Many of us will remember him, not so much for the many honors and decorations just mentioned, but for certain personal reasons. Those who studied under him will never forget his vast and versatile learning, and his typical Gallic clarity and eloquence. Young students to whom he showed such gracious and generous consideration, and who profited greatly from his advice, will remain forever grateful. Finally, by those more fortunate ones who knew him more intimately, he will always be remembered as a fine figure of a man, of remarkable courtesy and charm.

President McDougaL. I should like to add a personal note that by happy accident I came to know Professor Gidel when I was a student and learned first hand the deep encouragement that he gave younger men.

Those of us who have worked in the law of the sea know that he is the master of us all, and that it will be a long time before we see his equal.

Professor QUINCY WRIGHT. I would like to add a word about Norman Dwight Harris, whom I knew for many years, to what Professor Colegrove has written.

I would like particularly to mention the fact that Norman Dwight Harris, with his brothers, founded at the University of Chicago the Norman Waite Harris Memorial Foundation devoted to the study of international relations. I had the honor of operating this foundation for thirty-five years. Norman Dwight Harris was always interested in the work of this foundation. His father, Norman Waite Harris, had been the founder of the Harris Bank in Chicago, one of the largest banks in Chicago. And this foundation was a memorial to Norman Waite Harris, the father of Norman Dwight Harris, and his several brothers and sisters.

Professor Kenneth S. Carlston. As a former student of Professor Gidel, may I say that his teaching was marked by extraordinary learning, by his patience, and by kindness and humor, and it has been a great privilege to have had that memory of one's life.

Upon the recommendation of the Committee on Annual Awards presented by Chairman Herbert W. Briggs, the Society voted to award its Certificate of Merit to Mr. C. Wilfred Jenks for his recent book entitled The Common Law of Mankind.

Dr. Charles G. Fenwick reported for the Committee on Selection of Honorary Members and, upon the recommendation of the committee, the Society elected as an Honorary Member Dr. Luis Podestá Costa of Ar- 